TABLE A-3. continued

\begin{tabular}{lrrrl}
\hline & $\begin{array}{c}\text { Great } \\
\text { Britain }\end{array}$ & $\begin{array}{c}\text { United } \\
\text { States }\end{array}$ & Difference & \\
\hline 52 & 6.35 & 6.33 & -.02 & International Interactions \\
53 & 6.91 & 6.86 & -.05 & Public Administration Quarterly \\
54 & 7.04 & 6.94 & -.11 & Judicature \\
55 & 6.95 & 6.83 & -.12 & Journal of International Affairs \\
56 & 7.07 & 6.68 & -.39 & Asian Survey \\
57 & 5.30 & 4.84 & -.46 & Journal of Black Studies \\
58 & 8.10 & 7.52 & -.58 & Slavik Review \\
59 & 5.03 & 4.39 & -.64 & Experimental Study of Politics \\
60 & 8.22 & 7.58 & -.64 & China Quarterly \\
61 & 6.44 & 5.70 & -.74 & Political Science \\
62 & 9.26 & 8.45 & -.82 & Political Theory \\
63 & 8.17 & 7.24 & -.93 & Journal of Latin American Studies \\
64 & 8.83 & 7.87 & -.96 & Soviet Studies \\
65 & 8.64 & 7.68 & -.96 & European Journal of Political Research \\
66 & 5.59 & 4.42 & -1.16 & Simulation \& Games \\
67 & 12.35 & 10.75 & -1.60 & British Journal of Political Science \\
68 & 7.85 & 6.23 & -1.62 & Middle Eastern Studies \\
69 & 9.76 & 7.81 & -1.95 & International Affairs \\
70 & 6.94 & 4.98 & -1.97 & Women \& Politics \\
71 & 8.55 & 6.50 & -2.04 & Journal of Asian Studies \\
72 & 9.08 & 6.69 & -2.40 & Political Quarterly \\
73 & 10.77 & 7.71 & -3.05 & Government \& Opposition \\
74 & 12.87 & 7.73 & -5.14 & Political Studies \\
Mean & 7.55 & 8.37 & .82 & All journals \\
Mean & 9.85 & 7.90 & -1.95 & U.K.-based journals \\
Mean & 7.23 & 8.44 & 1.21 & U.S.-based journals \\
& & & &
\end{tabular}

\section{Note}

*The authors would like to thank all who took time to respond to this survey, and in particular the Political Studies Association for facilitating this research, and Micheal Giles for providing the original data for the American survey.

\section{References}

Crewe, Ivor, and Pippa Norris. 1991. Survey of the Reputation of Journals and Periodicals: Pluralist and Consensus Models. Paper for the PSA Annual Conference, April.

Christenson, James A., and Lee Sigelman.

\title{
Political Scientists and Public Policy Research*
}

\author{
James L. Sundquist, Senior Fellow Emeritus, Brookings Institution
}

I am deeply honored to be chosen for the Pi Sigma Alpha award of this distinguished organization, as well as by Tom Mann's kind words. I'm here by a lucky circumstance that the rules for this award were changed; it was designed, I understand, to honor political scientists who entered public service and rose to become Comptroller General or Ambassador to the United Nations or otherwise distinguish themselves, but this year it was opened to people who made the transition the other way-from public service to political science-so I became eligible.
So I'm here by virtue of a lucky accident. In fact, I'm here because of a whole series of lucky accidents that enabled me to even become a political scientist at all.

The first accident was that I fought part of World War II in the Budget Bureau, of all places, and met there a wonderful gentleman named George Graham, who twenty years later was Director of the Governmental Studies program at Brookings. I went to see him (I was working on Capitol Hill at the time), to see if there was any chance I might go to work for him. Well, he must
1985. "Accrediting Knowledge: Journal Stature and Citation Impact in Social Science." Social Science Quarterly 66: 964-75.

Garand, James C. 1990. "An Alternative Interpretation of Recent Political Science Journal Evaluations." PS: Political Science \& Politics XXIII: 448-51.

Giles, Micheal, and Gerald Wright. 1975. "Political Scientists' Evaluations of Sixtythree Journals."' PS: Political Science \& Politics VIII: 254-57.

, Francie Mizell, and David Patterson. 1989. "Political Scientists' Journal Evaluation Revisited." PS: Political Science \& Politics XX: 613-17.

Lester, James P. 1990. "Evaluating the Evaluators: Accrediting Knowledge and the Ranking of Political Science Journals." PS: Political Science \& Politics XXIII, September: 445-47.

McKay, David. 1988. "Why Is There a European Political Science?" PS: Political Science \& Politics XXI, Fall: 1051-56.

Robey, John. 1982. "Reputation vs. Citation: Who Are the Top Scholars in Political Science?"' PS: Political Science \& Politics XV: 199-200. have given it some thought, for the next time I saw him was three years later and he suddenly asked mequite out of the blue-" "How would you like to come to Brookings and write a book on Congress?' I mulled that over for all of two or three seconds before saying, "I'd love to. When can I start?" He said, "Of course, this has to be approved by the president of Brookings, Bob Calkins. I'll talk to him and call you." Pretty soon he called and told me, "Calkins says OK. Can you have lunch with me tomorrow and we'll talk about it further?"' 
So we did, and toward the end of the lunch he said, "Oh, by the way, you are about forty-five years old, aren't you?" I said, "No, George, I'm forty-nine." George's jaw dropped, he sort of went pale, and he said, "Oh, my gosh. I'll have to go back to Calkins on that. But maybe he'll approve it anyway." I said, "He darned well better. After your call yesterday, I went in to the Secretary of Agriculture and turned in my resignation." Well, pretty soon he called back and said, "Everything's all right. Calkins says that under the circumstances he'll go along.

So that was the second lucky accident: Brookings had such a primitive personnel system in those days that one could get hired without even submitting a resume or an application form or any other piece of paper on which one's advanced age would have had to be recorded.

The third lucky accident was that George talked to me in the spring of 1965 instead of the fall, because by fall Kermit Gordon had succeeded Calkins as president of Brookings. When my first book was sent to Kermit in manuscript for approval, he paid it some nice compliments and then said, "You know, it's ironic, but under the criteria we're applying now, we never would have hired you." From now on, he explained, we were insisting that every staff member have proper academic credentials. By luck, I got in just under the wire, as one of Bob Calkins' last acts, before the new management took over.

Right away, I had an identity crisis. I was entered in one of those directories and one day a request came in for me to bring my biography up to date. After my name, the next line said, "Occupation" and I was entered as "Government Official." Well, I thought, I'm not that anymore. I could put "former government official," but that makes me sound like a has-been. I can't put down "writer," because I haven't written anything yet. "Researcher" isn't specific and has no dignity. What in the world am I? So I took my identity crisis in to George and asked, "Can I call myself a political scientist?" He said, "I guess you can. Anybody can. There's nothing like a bar exam for political scientists." But I was still a little nervous about it; I had only two undergraduate courses in college that were labeled political science. My graduate degree was in public administration, and I didn't know-and am not sure yet-whether that is considered political science. But I had an idea. "I'll write a check to the American Political Science Association and ask for

.. . I had an idea. "I'll write a check to the American Political Science Association and ask for membership, and if they cash it, I'm in." I did, and they did, and that's how I became a political scientist. Fifteen years later, when I served a term as Treasurer of the APSA, I took one look at the so-called treasury and understood why they would accept a $\$ 50$ check from anybody, no questions asked.

membership, and if they cash it, I'm in." I did, and they did, and that's how I became a political scientist. Fifteen years later, when I served a term as treasurer of the APSA, I took one look at the so-called treasury and understood why they would accept a $\$ 50$ check from anybody, no questions asked.

One of your officers suggested that I reflect for a few minutes-but no more than that-on political scientists as public policy researchers, looking back on my more than a quarter of a century in an institution dedicated to that objective.

First, where does a public policy research institution find political scientists to do its work? The ideal recruit, of course, is a person who is experienced in both public policy- making and in research techniques. But here we have a very small pool to draw upon, in contrast to, say, the field of economics. The Brookings Economic Studies Program can find top-flight academic economists who have also been Director of the Budget, such as Charlie Schultze and Kermit Gordon himself; or Chairman of the Council of Economic Advisers, like Arthur Okun; or Director of the Congressional Budget Office, Alice Rivlin. They have an enormous pool of such people, because no Cabinet officer worth his or her salt -or any president, for that mattermakes a policy decision without an economist at his or her right hand (and a lawyer at the left, of course). But who needs political scientists? Only in one subfield of political science do they seem to need us: international relations. Top political scientists find their way onto the staffs of the National Security Council, the State Department and the intelligence agencies, and sometimes, like Jeane Kirkpatrick, even become ambassadors.

But on the domestic side, where are the people with policy experience? There are some able political scientists in the Congressional Research Service and some of them, such as Roger Davidson and Allen Schick, have gotten deeply involved in practical questions of designing and reforming policy-making institutions and systems. Charlie Clapp and Steve Horn came to Brookings from congressional staffs as background for their research on Congress, and Dick Nathan came with high-level executive branch experience. But the list about ends there. Even in the field of public administration, surprisingly few of the leading theorists and researchers ever take Washington assignments, the way the economists do.

So public policy research institutions have had a choice. Do they take people with broad governmental experience and try to make researchers out of them? Or do they seek out the best available academic political scientists and try to get them to do public policy research?

You can make an argument for the former. People who have been involved in trying to run the government are keenly, even passionately, 
aware of the weaknesses in our institutions, of what policymakers need to know to make their decisions, and of the gaps in their knowledge. When they undertake research, they are eager to find down-to-earth, practical answers to real problems that face the government every daywhich is what public policy research is all about.

But can they do research? Occasionally, over the years, when I was feeling lonely as the only nonacademic in the Governmental Studies program, I would remark that there must be, among the hundreds of bright people with rich governmental experience, a few who would be able to draw on that experience and bring insights that no scholar who had spent his or her whole career in a university could possibly possess. The answer was always, "You're probably right. But how do you know which ones?" How do you measure the research and writing potential of someone who has never researched and written? Are they capable of writing anything beyond their own memoirs? Can they conceptualize their experience? Can they broaden their perspective beyond what their own governmental role had been? There is no sure way to find out.

So the answer always was, let's go with the academics. At least, we know whether they can write, because we can read what they have published. We know they can do research, or they wouldn't be Ph.D.s. So I became the last of what might be called "old government hands" recruited by the Governmental Studies program, and that was almost twenty-six years ago. Since then, we have hired two very successful non-Ph.D.s, Steve Hess and Jim Reichley, but both were more professional journalists and free-lance writers than government types and they had established their credentials by having written books of Brookings quality. Otherwise, I am sure, we would never have taken the risk.

But recruiting public policy researchers from academia has its problems, too. The basic one is that there has been a disdain within our discipline for concrete, problemoriented, public policy research. As in other fields of science, applied research does not have a status equal to that of pure research. In the study of our institutions, applied research means recommending institutional reforms, and reform has become almost a dirty word because it involves value judgments and they, by definition, cannot be scientific. Political scientists who aspire to be true scientists get their recognition for their contributions to political theory, not for what they contribute to solving public problems. Theoretical works have a longer shelf life, too. They may be cited decades hence, while the applied research becomes out of date as soon as a public problem is resolved-which is

\section{Political scientists who} aspire to be true scientists get their recognition for their contributions to political theory, not for what they contribute to solving public problems.

rare-or changes character, which is constantly. Moreover, academic researchers know their next job is coming from a university, not from government. So academics tend to see as their audience their peers in the academy, not the policy makers who need their help and to whom the product of a place like Brookings is supposed to be directed.

I will give you two examples from Brookings' own experience, and the instances were so much alike that $I$ can deal with them together. In each case, the researcher had tackled an important, even urgent, practical problem requiring decision by the government. In each case, the author wrote a manuscript consisting of brilliant historical and analytical treatments of the problem, with a chapter or two placing it in its theoretical context. But in each case, that was all. When we saw the finished manuscript, I and some of my colleagues asked, "But where are your recommendations?" One replied, "I didn't set out to do a normative study. I set out to do a behavioral study." The other said, "I don't feel I know enough about the subject to make recommendations." We insisted, "Whatever you set out to do -and we don't see how the project ever got approved on that basis-you have spent two years of your life studying this question. You know more about it than anybody else alive, or you should. There are responsible policymakers out there who are struggling with this problem every day and have to make decisions. They need the best advice they can get, which means they deserve to get yours."

From this point the two cases diverged a little. In one case, the scholar peered through my door a couple of weeks later and said, "You know, this is fun. I've never tried to make recommendations before, but I'm really enjoying it."' In the end, this scholar came up with a final chapter consisting of some sound and practical recommendations that eventually had an impact on a piece of legislation. The other quite honestly could not find a panaceatic solution to the problem. A final chapter was written, but it recommended, in effect, only that the government do nothing but just continue to improvise and observe the results.

That second case did at least serve one purpose. When Bruce MacLaury became president of Brookings, he had to face the foundation and corporation executives who dole out money, and he kept getting asked, "So you're a public policy research institution. Well, tell us some of the policies that the government has adopted as the result of your research." Bruce found that a tough question. So he sent a memorandum to the program directors-I was one at the time-asking for illustrations of our influence. I found it a tough question too. Reviewing our Governmental Studies program, I could discover only one instance where we had clearly demonstrable influence: Dick Nathan and his associates had studied the Community Development Block Grant program and proposed a new formula for distributing the money, and the administration and the Congress adopted their proposal practically intact. But for the rest, I could only explain that our recommendations normally went out into 
the great public domain of ideas, where they mingled with everybody else's ideas and lost their identity. They might help to push governmental policy in a particular direction; for instance, Dave Stanley's and Hugh Heclo's writing surely developed and reinforced support for what eventually became the Senior Executive Service-but the chain of causation simply could not be traced so that we could say, "That was our idea. Without us, it would not have happened." But at the end of my memo to Bruce I wrote that there was one more case where the government had followed our explicit advice. Referring to the second case I discussed a minute ago, I said, "We recommended that the government do nothing. And it did nothing." Which is, of course, the recommendation that always has the highest probability of acceptance.

Up until the Persian Gulf war, at least, the American people were convinced that our political and governmental institutions were performing badly. Last spring's NORC poll found only 15 percent of its respondents had "a great deal of confidence" in the Congress. That figure hadn't been above 20 percent since 1973. And the executive branch doesn't fare much better. It rated only 23 percent on the "great deal of confidence" scale. In an exit poll last November, 76 percent of those voting were dissatisfied with the way Congress was doing its job, and 65 percent said they trusted the government in Washington "to do what is right" only some of the time or never. Newspaper reports from all across the country said the voters were angry. I think we can assume that after our Persian Gulf victory euphoria wears off and the people look inward again at how well we're handling our domestic problems, confidence in our national government will fall back to the appalling levels of the last twenty years.

So the time is at hand to ask political scientists everywhere what we asked those two researchers I spoke of: "What are your recommendations? You've spent your whole lives studying these institutions. You know more about them than anybody else. Are they really malfunctioning? If so, what can be done about them?
Are there things wrong with the whole governmental structure that go back to the Constitutional design itself?" We need to restore applied research in political science, in the form of institutional analysis and institutional design, to the status it had at the very beginning of our discipline, when governmental reforms such as designing civil service and budget systems, modernizing Congress, strengthening the powers and staff facilities of the president, and governors and mayors and city managers, reorganizing government departments, and so on occupied the

When Bruce MacLaury
became president of
Brookings, . . he kept
getting asked, "So you're
a public policy research
institution. Well, tell us
some of the policies that
the government has
adopted as the result of
your research."'

best minds in political science. And again in the 1940s, when the APSA set up its committees on congressional reorganization and on political parties. We should be analyzing and appraising institutional performance all the time, but it is especially urgent now when our institutions are in such low esteem. We need to examine our governmental system and all of its parts and stimulate, and engage in, a great debate as to how, where we find them faulty, we can improve them.

I am happy to say that we seem to be moving in that direction. There is a lot more high-quality institutional analysis, the kind that leads to recommended reforms, being carried out than was the case only a few years ago. To name just a few books of that type published by political scientists in the past five years alone (my list has a heavy bias toward Brookings books, of course): There is the Brookings symposium edited by John Chubb and Paul Peterson entitled Can the Government Govern?, which asks the right question even if it could not come up with a clear answer. There are other symposia: Tom Mann's on the president and Congress in foreign affairs, Jim Reichley's on strengthening political parties, Jim Thurber's on divided government. David Magleby and Candice Nelson have published a book on financing congressional campaigns, with the word "reform" in the subtitle. Don Robinson and James MacGregor Burns have books recommending constitutional reform. Larry Sabato has one on strengthening the parties. John Chubb and Terry Moe have created something of a sensation with their quite specific recommendations for reorganizing every school system in the country. And there are two notable comparative works about to be published-David Mayhew's comparing the relative effectiveness of unified party government and divided government in the United States, and Kent Weaver and Bert Rockman's edited volume of case studies comparing the performance of our separation-of-powers system with that of various parliamentary governments around the globe.

The problems of methodology in studies of institutional reform are, of course, enormous, and that has held us back. Far easier to describe institutional behavior than to prescribe reforms that might change it. There is the law of unintended consequences so often cited: Reforms never work the way they were intended, and often make things worse, so better let well enough alone. And how does one measure the efficacy of governmental institutions anyway? Weaver and Rockman are pioneering a careful set of criteria for measuring the adequacy of governmental performance that I believe will prove quite useful and can be refined and built upon. In the meantime, I have been using a rather simple criterion myself: If the President and the Congress, and both parties, and the preponderance of opinion outside the government say something is a problem that should be dealt with-in other words, if there is a clear national consensus-and the government still fails to act effective- 
ly, then the institutions are not performing as they should. By that criterion, the preeminent instance of government failure is now, and has been for a decade or more, our outrageous budget deficit. What has been wrong with our institutions on this question? Why can't we do better than a Gramm-Rudman-Hollings Act and a summit meeting that only papers over the problem? Why has the government been so impotent? What are the institutional remedies? What about divided government? That has seemed to me to be at the bottom of most of our problems, as I have written elsewhere, because it not only makes for deadlock and delay but destroys the responsibility and accountability that unified party government offers. Mayhew doesn't find the record of divided government to be all that bad, but he admits to methodological difficulties in making his assessment.

Anyway, the appraisal, reform, and redesign of institutions is the great challenge for political science today, in my view, and especially for those in our discipline who live and work at or near our national capital. I hope we will rise to the challenge and bear down on these questions of institutional performance and institutional failures and inadequacies. And, when we do, let's have those concluding chapters setting forth our recommendations.

\title{
Running the Good Race, Part 1* \\ High Anxiety: Some Lessons for Graduate Students Entering the Profession
}

\author{
John D. Harman, St. John Fisher College
}

\begin{abstract}
Editor's Note: From time to time PS has featured articles advising job candidates and junior faculty members on how to run a good employment race in the academic market. Beginning with this issue, we will publish a series of articles on job finding, teaching, publication, promotion and tenure. Some of the articles will be new material, others will be updates of previously published essays. You are encouraged to submit articles to the series if you see areas which have been overlooked or deserve more attention.
\end{abstract}

A fter preliminary or comprehensive examinations have been successfully completed, questions about employment after graduation naturally arise. "What kind of department should I apply to?" and "What will they expect of me?" are two crucial ones. Answers to these should take into account the following points.

First, the two main aspects of political science are research and teaching. Research generally translates into inquiry which results in the delivery of papers at scholarly conferences, and the publication of books and articles in scholarly journals. It also often includes the securing of grants from government or private sources to support this inquiry, an activity which brings additional resources into the college by helping to pay for the researcher's "institutional overhead" expenses (secretaries, fringe-benefits, building and maintenance costs, etc.). Teaching consists primarily of the preparation and administration of coursework, but can include activities such as the supervision of internships, independent study projects, and graduate work, advising, reading courses or tutorials, and the like.

Second, while colleges differ tremendously in the emphasis they place on these two aspects, they generally fall into three groups-those which emphasize research, those which emphasize teaching, and those which expect both. The key to differentiating them lies in the number of courses required for a full load and the amount of support given to research and "professional activities" (associated with dissemination of the results of research)-travel money, computer access, copying privileges, telephone and mailing support, teaching and research assistants, and clerical support. Research-oriented departments will usually have a minimal teaching load-two courses per semester/quarter is typical-and generous provision of professional activ-

\section{Note}

* Remarks presented at the spring meeting of the National Capital Area Political Science Association (in response to receipt of the Association's 1991 Pi Sigma Alpha Award), March 2, 1991

\section{About the Author \\ James L. Sundquist is a former Budget Bureau staff member, aide to a United States Senator, and Deputy Under Secretary of Agriculture who later spent 20 years (1965-85) as a Senior Fellow at the Brookings Institu- tion, two of those as director of the Govern- mental Studies Program. He is the author of six Brookings books, some of which contain recommendations for institutional reform.}

ity/research support. Teachingoriented departments will usually require substantially greater teaching loads-four or five courses per semester/quarter-with minimal professional support. Departments which expect both will fall between these two extremes.

Each prospective political scientist thus must answer for him/herself the question of how much commitment can be given to research or teaching. Teaching and research both require substantial effort to do well and are certainly fundamental intellectual pursuits. The answer arrived at regarding this question should determine the type of department to which one applies.

\section{Departmental Expectations}

The question of departmental expectations normally focuses on a specific event-the tenure decision. Most colleges grant tenure-permanent appointments from which professors cannot be fired without cause -after some probationary period, in most cases six years. This often coincides with the decision to promote assistant professors, typically to the associate professor level. Most also must release, or cannot reappoint, 